\title{
Effects of genetic potential on the lysine requirement and economic results of simulated broiler flocks
}

\author{
Bernard LeClercQ, Catherine BeAumont* \\ INRA, Recherches avicoles, 37380 Nouzilly, France \\ (Received 24 December 1999; accepted 17 January 2001)
}

\begin{abstract}
The effect of lysine dietary concentration (expressed as g of lysine per $\mathrm{kg}$ of feed) on growth from 20 to 40 days of age in male broiler flocks was studied by simulating flock performance. A total of 17 sets of parameters was considered. Different hypotheses were made on the means, variances and covariances of initial body weight ( $20 \mathrm{~d}$ of age), live weight gain (20 to $40 \mathrm{~d}$ ), lipid content of gain and of a factor affecting the energy requirement for maintenance. The effect of dietary lysine concentration on individual live weight gain was simulated according to a "broken line" model which resulted in a curvilinear variation of flock performance with lysine concentration, as usually observed. The lipid content of gain was the major characteristic of the genotype accounting for the mean lysine requirement of flocks: the latter increased by $1.935 \mathrm{~g}$ per $\mathrm{kg}$ of feed, i.e. $20.1 \%$, when the former decreased from 21 to $13 \%$. Growth rate and the factor affecting energy requirement for maintenance also exerted significant effects: when weight gain increased from 1550 to $1950 \mathrm{~g}$, the lysine requirement increased by $6 \%$. Lean and efficient flocks required diets with a higher lysine concentration. Heterogeneity for fatness also tended to increase the variability of lysine requirement. The minimum feeding cost per kg of gain was reached on average when the mean weight gain of flocks was $97.9 \%$ of maximum gain, flock feed conversion ratio (FCR) was about $100.7 \%$ of the minimum FCR, and when the lysine requirement of $65.8 \%$ of individuals was satisfied.
\end{abstract}

chicken / growth / lysine / requirement / adiposity / simulation

Résumé - Étude, par simulation, des influences respectives de plusieurs caractéristiques génétiques sur le besoin en lysine et les résultats économiques de troupeaux de poulets de chair. L'effet sur la croissance de la concentration du régime en lysine digestible a été étudié par simulation, chez des poulets mâles entre 20 et 40 jours. Cette concentration était exprimée en g par kg d'aliment et 17 situations ont été considérées. Les hypothèses initiales portaient sur les distributions du poids vif à 20 jours, du gain de poids, de la teneur en lipides du gain de poids et d'un facteur caractérisant le besoin énergétique d'entretien. Les moyennes, écarts types et corrélations entre ces paramètres différaient. En simulant le gain de poids de chaque individu en fonction de la teneur du régime en lysine selon un modèle dit « en ligne brisée », nous avons observé une réponse curvilinéaire du troupeau. La teneur en lipides du gain de poids est le paramètre d'origine génétique influençant le plus le besoin en lysine : ce dernier augmente de 1,935 g par kg d'aliment (soit 20,1\%) quand le premier

* Correspondence and reprints 
passe de 21 à $13 \%$. La vitesse de croissance et le facteur affecté au besoin énergétique d'entretien exercent également un effet significatif sur le besoin en lysine : quand le gain de poids passe de 1550 à $1950 \mathrm{~g}$, le besoin en lysine augmente de $6 \%$. L'hétérogénéité de l'engraissement tend à augmenter la variabilité du besoin moyen d'un troupeau. Le coût alimentaire minimum d'un $\mathrm{kg}$ de gain de poids est, en moyenne, obtenu quand le gain de poids moyen du troupeau atteint $97,9 \%$ du maximum, l'indice moyen 100,7 \% du minimum et que le besoin en lysine de 65,8 \% des individus est couvert.

poulet / croissance / lysine / besoin / adiposité / simulation

\section{INTRODUCTION}

Amino acid requirements of broiler chickens is a very important parameter of food formulation, both in terms of cost and environmental consequences. It has been suggested that growth rate could influence these requirements $[9,10]$. Similarly, it has recently been shown that the lipid content of live weight could modify nutritional responses to variations of amino acid concentrations in diets; indeed, lean birds are more sensitive to protein or amino acid deficiencies $[1,14,15]$. However, the relationships between amino acid requirement and the genetic value of animals have rarely been studied. As these characteristics vary between individuals within a flock, they may result in differences in responses. It therefore seems necessary to compute the flock response according to simulations of individual performance.

Modelling has often been based on absolute values of amino acids [6], i.e. absolute amounts of amino acids required to reach a given performance, such as maintenance or growth [4]. Thus the Reading model [6] has been developed to express the performance of layer and broiler flocks according to mean amino acid intake and not dietary lysine concentration. In this model, individual responses to amino acid intake are assumed to follow a "broken line" model but the flock response, (i.e. the mean of individual responses) is expected to be curvilinear. However, this result had never been confirmed through the simulation of a whole flock. Furthermore, in the Reading model, only individual weight gain and mean live weight are taken into consideration. However, in practical conditions, it is more useful to express responses as a function of dietary amino acid content $\left(\mathrm{g} \cdot \mathrm{kg}^{-1}\right)$ rather than of amino acid intake $(\mathrm{g})$. The main problem is then to assess individual feed intakes, which may be influenced by many factors depending on either feed or bird characteristics.

Because of the curvilinearity of performance responses to lysine concentration, determining the requirement is difficult. The only way to accurately assess the optimum lysine concentration is thus to use an economic approach and choose the concentration which minimises feed costs.

The present study was undertaken to simulate flock responses to varying levels of lysine concentration, which is the most limiting amino acid in diets for growing birds. Besides growth rate and live weight, other genetic characteristics known to influence feed consumption such as body composition and energy requirement for maintenance have been taken into consideration. The latter was also considered since it has been shown that it depends on genetic control in broilers [18] as well as in layers [5, 7, 8]. The aims of this study were: (1) to verify that individual responses that follow a broken line model result in a curvilinear response of flocks, (2) to assess the relative influences of fatness, growth rate and energy requirement for maintenance, on the lysine requirement, expressed as g digestible lysine 
per $\mathrm{kg}$ of feed, and (3) to develop an economic approach based on flock characteristics.

\section{MATERIALS AND METHODS}

Seventeen simulations were performed to compute the means and standard deviations of lysine requirement, growth rate, feed consumption and feed conversion ratio between 20 and 40 days of age in virtual flocks of 10000 male broiler chickens.

\subsection{Simulation model}

In each flock, individuals were characterised by their genetic value for four traits: body weight (in $\mathrm{kg}$ ) at 20 days $\left(\mathrm{y}_{1}\right)$, weight gain in $\mathrm{kg}$ between 20 and 40 days $\left(\mathrm{y}_{2}\right)$, lipid content of gain (in $\mathrm{g} \cdot \mathrm{g}^{-1}$ called $\mathrm{y}_{3}$ ) and a parameter called efficiency of energy utilisation for maintenance $\left(\mathrm{y}_{4}\right)$. These values were obtained from normal distributions using the Splus software [3]. From these 4 parameters, 9 new variables were calculated. The protein content of gain (Prot) was estimated using a linear regression on lipid content based on data observed from genetically lean and fat lines [15]:

$$
(\text { Prot })=0.225-0.27 \mathrm{y}_{3} \text {. }
$$

The equations used for simulations were drawn independently from the literature and personal observations. The first system of computation of energy requirement $\left(\mathrm{E}_{\mathrm{m} 1}\right.$ and $\mathrm{E}_{\mathrm{g} 1}$ ) was issued from a nutritional study performed on two experimental lines (a lean and a fat line) [13] using the restriction procedure:

$\left(\mathrm{E}_{\mathrm{m} 1}\right)=102 \times\left(\mathrm{y}_{1}+\left(\mathrm{y}_{2} / 2\right)\right)^{0.75} \times 20$ days $\times \mathrm{y}_{4}$

$\left(E_{\mathrm{g} 1}\right)=\mathrm{y}_{2} \times\left((14.06 \times\right.$ Prot $\left.)+\left(10.1 \times \mathrm{y}_{3}\right)\right)$.

The second system $\left(\mathrm{E}_{\mathrm{m} 2}\right.$ and $\left.\mathrm{E}_{\mathrm{g} 2}\right)$ was based on a recent unpublished study by Carré (personal communication) using ad libitum feeding of a commercial cross (ISA 915).

$$
\left(\mathrm{E}_{\mathrm{m} 2}\right)=130 \times\left(\mathrm{y}_{1}+\left(\mathrm{y}_{2} / 2\right)\right)^{0.75} \times 20 \text { days } \times \mathrm{y}_{4}
$$

$\left(E_{\mathrm{g} 2}\right)=\mathrm{y}_{2} \times\left((9.74 \times\right.$ Prot $\left.)+\left(10.47 \times \mathrm{y}_{3}\right)\right)$.

Feed consumption (F, in $\mathrm{kg}$ ) was computed as:

$$
(F)=\left(E_{m}+E_{g}\right) / 3200
$$

while lysine requirements for maintenance and for gain (in $\mathrm{g} \cdot \mathrm{kg}^{-1}$ ) were drawn from [4] assuming that the protein content of gain was $175 \mathrm{~g}$ per $\mathrm{kg}$ to be:

$\left(\right.$ Lys $\left._{\mathrm{m}}\right)=\left(\left(\mathrm{y}_{1}+\left(\mathrm{y}_{2} / 2\right)\right) \times 0.082 \times 20\right.$ days $) / \mathrm{F}$

and

$$
\left(\mathrm{Lys}_{\mathrm{g}}\right)=\left(\mathrm{y}_{2} \times \operatorname{Prot} \times 0.086\right) / \mathrm{F} .
$$

The hypothesis was made that the individual gain (Gain) was proportional to the ratio of the difference between lysine concentration ( $\mathrm{x}$, expressed in $\mathrm{g} \cdot \mathrm{kg}^{-1}$ ) and lysine requirement for maintenance to the lysine requirement for growth. In other words this means that growth rate is linearly related to the excess of lysine concentration over maintenance requirement, until the maximum growth rate is reached (broken line model):

$$
\begin{aligned}
\text { Gain }=y_{2} \times\left(\left(x-\operatorname{Lys}_{m}\right) /\left(\operatorname{Lys}_{\mathrm{g}}\right)\right) \\
\text { if }\left(\operatorname{Lys}_{\mathrm{m}}+\mathrm{Lys}_{\mathrm{g}}\right) \geq \mathrm{x} \\
=\mathrm{y}_{2} \quad \text { if }\left(\mathrm{Lys}_{\mathrm{m}}+\mathrm{Lys}_{\mathrm{g}}\right)<\mathrm{x} .
\end{aligned}
$$

\subsection{Calibration of the model}

Simulations 1 and 2 were performed to choose the energy equation systems which best fit usually observed data. Energy requirements were computed using equations (2) and (3) for simulation 1 and equations (4) and (5) for simulation 2. The means and standard errors used in simulations were $850 \mathrm{~g} \pm 70 ; 1750 \mathrm{~g} \pm 262 ; 0.17 \pm 0.05$ and $1 \pm 0.05$ for $\mathrm{y}_{1}, \mathrm{y}_{2}, \mathrm{y}_{3}$ and $\mathrm{y}_{4}$ respectively. The correlations between parameters were assumed to be equal to zero. 


\subsection{Validation of the model}

Simulation 3 produced data close to those of commercial crosses performed at present [17]. The means and standard errors were the same as before but in this simulation and in the following simulations, it was assumed, as usually observed in commercial flocks, that the correlation coefficients between live weight at 20 days and gain, between gain and the lipid content of gain [12], and the lipid content coefficient affected to energy requirement [7], were equal to $0.5,0.5$ and -0.5 respectively.

\subsection{Analysis of the sensitivity of the model}

In the other 14 simulation hypotheses, the same means and standard deviations were used for all parameters but one. Simulations 4 to 7 were performed to assess the effect of the mean lipid content of gain on lysine requirement and performance responses. Indeed, the lipid content of gain varied from $130 \mathrm{~g} \cdot \mathrm{kg}^{-1}$ to $210 \mathrm{~g} \cdot \mathrm{kg}^{-1}$ by $20 \mathrm{~g} \cdot \mathrm{kg}^{-1}$ which are the lowest and the highest limits observed in experimental lines selected for low- or high- fat content [15]. The coefficient of variation of lipid content was kept constant (30\%) which resulted in standard deviations varying from 0.038 to 0.062 .

Simulations 8 to 11 were undertaken to estimate the effect of heterogeneity of lipid content on mean lysine requirement and on flock responses to dietary lysine. The coefficients of variation were equal to $7.5,10$, 15 and $40 \%$.

Simulations 12 and 13 were performed to observe the effect of growth rate. It varied from $1550 \mathrm{~g}$ to $1950 \mathrm{~g}$ while the coefficient of variation remained unchanged (and equal to $15 \%$ ). Simulations 14 to 17 allowed to assess the effect of the factor affecting energy requirement for maintenance, since it was demonstrated that there is a genetic control of energy requirement for maintenance
$[5,7,8,18]$. The latter was equal to 0.85 , $0.90,1.1$ and 1.15 , respectively (i.e. values close to those observed in experimental lines [18]), while the coefficient of variation was maintained at $5 \%$.

For each simulation 28 lysine concentrations were used: 7.0, 7.5, 8.0, 8.1, 8.2, ..., $9.9,10.0,10.25,10.5,10.75,11.0$, and $11.5 \mathrm{~g} \cdot \mathrm{kg}^{-1}$.

\subsection{Determination of the minimum feeding cost}

Using the data from these simulations, the feeding cost of $1 \mathrm{~kg}$ of gain was computed by multiplying FCR by the price of $1 \mathrm{~kg}$ of feed. The dietary lysine concentration which minimises this feeding cost was thus assessed and the corresponding mean weight gain and FCR were expressed as a percentage of maximum gain of flocks or minimum value of FCR. Finally, the proportion of birds whose lysine requirement was reached at this lysine concentration was estimated assuming that distributions of lysine requirements were normal.

\section{RESULTS}

\subsection{Simulation of a normal commercial flock}

In simulations 1 and 2, respectively, mean lysine requirement ( \pm standard deviations) was equal to $8.251 \pm 1.096$ and $8.606 \pm$ 1.307, and minimum FCR of flocks was equal to 1.872 and 1.801 (Tab. I). The skewness coefficients were equal to 0.33 and 0.47 , respectively, and were significantly different from 0 while the kurtosis coefficients, estimated at 3.17 and 3.53 , were significantly higher than 3 , suggesting that the distributions were very close to normality. These results suggested that $\mathrm{E}_{\mathrm{m} 2}$ and $\mathrm{E}_{\mathrm{g} 2}$ were better predictors of energy requirement and feed consumption than $\mathrm{E}_{\mathrm{m} 1}$ and $\mathrm{E}_{\mathrm{g} 1}$. Indeed, the absolute value of minimum 
Table I. Coefficients of correlation between lysine requirement and initial body weight $\left(\mathrm{y}_{1}\right)$, weight gain $\left(y_{2}\right)$, lipid content of gain $\left(y_{3}\right)$, coefficient of energy utilisation $\left(y_{4}\right)$ for maintenance in simulations 1 and 2 performed to compare the two systems of computations of energy requirements (see Eqs. (2) to (5) of text).

\begin{tabular}{lcc}
\hline & Simulation 1 & Simulation 2 \\
\hline Initial body weight $\left(\mathrm{y}_{1}\right)$ & -0.060 & -0.075 \\
Weight gain $\left(\mathrm{y}_{2}\right)$ & 0.211 & 0.243 \\
Lipid content of gain $\left(\mathrm{y}_{3}\right)$ & -0.963 & -0.948 \\
Coefficient of energy utilisation for maintenance $\left(\mathrm{y}_{4}\right)$ & -0.116 & -0.127 \\
\hline
\end{tabular}

Table II. Results of simulation 3 (performed to validate the model of simulation).

\begin{tabular}{lc}
\hline Mean digestible lysine requirement $\left(\mathrm{g} \cdot \mathrm{kg}^{-1}\right.$ feed $)$ & $8.556( \pm 1.012)$ \\
Minimum FCR of flock & 1.8096 \\
Correlation coefficient between lysine requirement and: & 0.060 \\
$\quad$ Initial body weight $\left(\mathrm{y}_{1}\right)$ & -0.331 \\
Weight gain $\left(\mathrm{y}_{2}\right)$ & -0.970 \\
Lipid content of gain $\left(\mathrm{y}_{3}\right)$ & 0.450 \\
Coefficient of energy utilisation for maintenance $\left(\mathrm{y}_{4}\right)$ & \\
Partial* correlation coefficients between lysine requirements and: & 0.247 \\
Initial live weight $\left(\mathrm{y}_{1}\right)$ & 0.731 \\
Weight gain $\left(\mathrm{y}_{2}\right)$ & -0.166 \\
Coefficient of energy utilisation for maintenance $\left(\mathrm{y}_{4}\right)$ & \\
\hline
\end{tabular}

* At a given lipid content $\left(\mathrm{y}_{3}\right)$.

FCR, as well as the shape of the response curves of gain and FCR to dietary concentration, were closer to those usually observed in commercial flocks $[11,17]$. The former system was thus used in all the other simulations.

The results of simulation 3 are presented in Table II. Minimum FCR and lysine requirement were very close to those of commercial flocks $[11,17]$. Indeed, in this study, FCR of control treatments was about 1.71 and lysine requirement varied between 9.4 and $10.2 \mathrm{~g}$ digestible lysine per $\mathrm{kg}$ of diet. Skewness and kurtosis of the individual lysine requirements were close to respective values of 0 and 3 , suggesting that this distribution was close to normality.

\subsection{Effect of mean and variance of the lipid content of gain}

As seen in Table III, digestible lysine requirement decreased on average by $0.242 \mathrm{~g}$ lysine per $\mathrm{kg}$ feed when lipid content per $\mathrm{kg}$ of gain increased by $0.010 \mathrm{~g}$ per gram of gain. In parallel, standard deviation of lysine requirement and FCR increased, but to a much lower extent, from $8.35 \%$ to $15.4 \%$.

As shown in Table IV, the mean of individual lysine requirements was not significantly affected by heterogeneity of lipid content. However, its standard deviation increased. 
Table III. Influence of lipid content of gain on mean and standard deviations (between parentheses) of digestible lysine requirement $\left(\mathrm{g} \cdot \mathrm{kg}^{-1}\right.$ feed) and on minimum FCR.

\begin{tabular}{cccc}
\hline Lipid content $\left(\mathrm{g} \cdot \mathrm{g}^{-1}\right)$ & Simulation & $\begin{array}{c}\text { Mean lysine } \\
\text { requirement } \\
\text { (standard deviation) }\end{array}$ & Minimum FCR \\
\hline 0.130 & 4 & 9.590 & 1.7073 \\
0.150 & 5 & $(0.801)$ & 1.7580 \\
0.170 & 3 & 9.064 & 1.8096 \\
0.190 & 6 & $(0.899)$ & 1.8584 \\
& & 8.556 & \\
0.210 & 7 & $(1.012)$ & 1.9095 \\
& 7 & $(1.086)$ & \\
\hline
\end{tabular}

Table IV. Effects of heterogeneity of lipid content of gain on mean and standard deviations (between parentheses) of digestible lysine requirement $\left(\mathrm{g} \cdot \mathrm{kg}^{-1}\right.$ feed) and on minimum FCR. Lipid content of gain was maintained constant at $17 \%$.

\begin{tabular}{cccc}
\hline $\begin{array}{l}\text { Coefficient of variation } \\
\text { of lipid content }(\%)\end{array}$ & Simulation & $\begin{array}{c}\text { Mean Lysine requirement } \\
\text { (standard deviation) }\end{array}$ & Minimum FCR \\
\hline 7.5 & 8 & 8.528 & 1.8006 \\
& & $(0.235)$ & 1.8028 \\
10 & 9 & 8.521 & 1.8043 \\
15 & 10 & $(0.285)$ & \\
& & 8.527 & 1.8097 \\
30 & 3 & $(0.440)$ & 1.8141 \\
& & 8.556 & \\
\hline
\end{tabular}

\subsection{Effect of growth rate and of the factor affecting energy requirement for maintenance}

According to the data in Table V, when the lipid content of gain was kept constant, the mean of lysine requirements increased as mean weight gain increased. Concomitantly a drop in FCR was observed, which confirms most observations of variations between growth rate and FCR.

As presented in Table VI, results of simulations 14 to 17 showed that reducing the factor affecting energy requirement for maintenance increased lysine requirement 
and reduced FCR. In the range of variation corresponding to data observed in experimental lines [18], the effects of this factor were similar to those observed for lipid content.

\subsection{Economic approach of different simulations}

Results of these computations are given in Table VII. Whatever the simulation hypotheses, similar trends were observed for the lysine concentration minimising feeding costs and for the mean lysine requirement of flocks (Tabs. II to VIII). The former was always higher than the latter and both varied little with simulations. On average, the concentration that minimises costs (economic optimum) covered requirements of $65.8 \%$ of chickens and allowed the flocks to exhibit a performance which was on average $97.9 \%$ (97.1 to $99.2 \%$ ) of maximum gain and $100.7 \%$ (100.2 to $101.1 \%$ ) of minimum FCR. These percentages were not deeply influenced by simulation hypotheses.

Table V. Effects of weight gain between 20 and 40 days on mean and standard deviations (between parentheses) of digestible lysine requirement ( $\mathrm{g} \cdot \mathrm{kg}^{-1}$ feed) and on minimum FCR. The coefficient of variation of weight gain is $15 \%$.

\begin{tabular}{cccc}
\hline Mean gain $(\mathrm{g})$ & Simulation & $\begin{array}{c}\text { Mean lysine requirement } \\
\text { (standard deviation) }\end{array}$ & Minimum FCR \\
\hline 1550 & 12 & 8.303 & 1.8640 \\
$(232)$ & & $(0.951)$ & \\
1750 & 3 & 8.556 & 1.8096 \\
$(262)$ & & $(1.012)$ & 1.7630 \\
1950 & 14 & 8.796 & \\
$(292)$ & & $(1.067)$ & \\
\hline
\end{tabular}

Table VI. Effects of the factor of energy utilisation for maintenance on mean and standard deviations (between parentheses) of digestible lysine requirement $\left(\mathrm{g} \cdot \mathrm{kg}^{-1}\right.$ feed) and on minimum FCR.

\begin{tabular}{lccc}
\hline $\begin{array}{l}\text { Factor of energy } \\
\text { utilisation } \\
\text { (standard deviation) }\end{array}$ & Simulation & $\begin{array}{c}\text { Mean lysine requirement } \\
\text { (standard deviation) }\end{array}$ & Minimum FCR \\
\hline 0.85 & 14 & 9.094 & 1.7055 \\
$(0.425)$ & 15 & $(1.140)$ & 1.7385 \\
0.90 & & 8.920 & \\
$(0.45)$ & 3 & $(1.093)$ & 1.8096 \\
1.00 & & 8.556 & 1.8791 \\
$(0.50)$ & 16 & $(1.012)$ & \\
1.10 & & 8.231 & 1.9139 \\
$(0.055)$ & 17 & $(0.945)$ & \\
1.15 & & 8.076 & $(0.896)$ \\
$(0.575)$ & &
\end{tabular}


Table VII. Estimated digestible lysine concentration $\left(\mathrm{g} \cdot \mathrm{kg}^{-1}\right.$ feed) required to minimise feeding cost ratio of maximum weight gain and of minimum FCR achieved as well as percentage of birds whose lysine requirements are covered at this concentration. The price of the basal diet ( $7 \mathrm{~g}$ lysine per $\mathrm{kg}$ ) is hypothesised to be 0.20 euro $\cdot \mathrm{kg}^{-1}$ and the price of lysine 0.0023 euro $\cdot \mathrm{g}^{-1}$.

\begin{tabular}{|c|c|c|c|c|c|}
\hline Simulation & $\begin{array}{l}\text { Minimum } \\
\text { Feeding cost } \\
\text { (euro } \cdot \mathrm{kg}^{-1} \text { gain) }\end{array}$ & $\begin{array}{c}\text { Lysine } \\
\text { concentration } \\
\left(\mathrm{g} \cdot \mathrm{kg}^{-1}\right)\end{array}$ & $\underset{\text { gain }}{\% \text { maximum }}$ & $\underset{\text { FCR }}{\% \text { minimum }}$ & $\begin{array}{c}\% \text { birds } \\
\text { whose } \\
\text { requirement } \\
\text { are satisfied }\end{array}$ \\
\hline 3 & 0.3732 & 9.00 & 97.7 & 100.8 & 67.0 \\
\hline 4 & 0.3550 & 9.90 & 98.1 & 100.6 & 65.1 \\
\hline 5 & 0.3639 & 9.45 & 98.0 & 100.7 & 66.6 \\
\hline 6 & 0.3817 & 8.65 & 97.7 & 100.8 & 69.3 \\
\hline 7 & 0.3909 & 8.20 & 97.2 & 101.0 & 67.8 \\
\hline 8 & 0.3675 & 8.60 & 99.2 & 100.2 & 62.0 \\
\hline 9 & 0.3682 & 8.60 & 99.0 & 100.3 & 60.9 \\
\hline 10 & 0.3692 & 8.70 & 98.8 & 100.4 & 65.3 \\
\hline 11 & 0.3762 & 9.20 & 96.9 & 101.1 & 64.7 \\
\hline 12 & 0.3833 & 8.80 & 98.0 & 100.7 & 70.0 \\
\hline 13 & 0.3646 & 9.15 & 97.2 & 100.9 & 63.0 \\
\hline 14 & 0.3539 & 9.45 & 97.1 & 100.9 & 62.2 \\
\hline 15 & 0.3601 & 9.30 & 97.3 & 100.9 & 63.6 \\
\hline 16 & 0.3859 & 8.70 & 98.0 & 100.7 & 69.0 \\
\hline 17 & 0.3923 & 8.55 & 98.1 & 100.7 & 70.2 \\
\hline
\end{tabular}

\subsection{Relationships between dietary lysine concentration and performance}

Using data of simulation 3 only, i.e. the closest to actual commercial flocks, the variation of the ratio of observed performance to maximum performance with dietary lysine concentration was computed. From Table VIII, it can be observed that the lysine concentration required to minimise feeding cost $\left(9 \mathrm{~g} \cdot \mathrm{kg}^{-1}\right)$ was only $5 \%$ higher than the mean requirement of broilers $\left(8.56 \mathrm{~g} \cdot \mathrm{kg}^{-1}\right)$. At the former concentration, $67 \%$ of chickens had reached their theoretical lysine requirement and their maximum performance. The relative range of variation of live weight was wider than that of FCR. Finally, it can be observed that the higher the lysine concentration, the heavier the final live weight and the smaller its standard deviation. From 7 to $10 \mathrm{~g}$ lysine per $\mathrm{kg}$ feed, the coefficient of variation dropped from $15.5 \%$ to $12 \%$.

\section{DISCUSSION}

\subsection{Choice of equations for the prediction of energy requirement}

Systems $\mathrm{E}_{\mathrm{m} 2}$ and $\mathrm{E}_{\mathrm{g} 2}$ seemed to better fit the presently observed data, as they led to response curves of gain and FCR to dietary lysine and in particular to a minimum FCR close to that recently observed $[11,17]$ in commercial flocks exhibiting a similar growth curve and lipid content. This system was thus used for all other simulations.

It was assumed that there was a linear relationship between dietary lysine concentration and individual gain below the maximum gain level. This hypothesis, which has been used by many investigators [2], 
Table VIII. Relationships between digestible lysine concentration, body weight at 40 days of age, weight gain and FCR (both expressed as a ratio of optimal performances) and percentage of birds whose lysine requirement are covered. The hypotheses of simulation are described in paragraph 2.5 and the hypotheses of prices in Table VII. Standard deviations are given between parentheses.

\begin{tabular}{|c|c|c|c|c|c|}
\hline $\begin{array}{l}\text { Lysine } \\
\text { concentration } \\
\left(\mathrm{g} \cdot \mathrm{kg}^{-1}\right)\end{array}$ & $\begin{array}{c}\text { Feeding } \\
\text { Cost } \\
\left(\text { euro } \cdot \mathrm{kg}^{-1} \text { ) }\right.\end{array}$ & $\begin{array}{c}\text { Gain } \\
\text { (\% maximum) }\end{array}$ & $\begin{array}{c}\text { FCR } \\
(\% \text { minimum })\end{array}$ & $\begin{array}{c}\text { Body } \\
\text { weight (g) }\end{array}$ & $\begin{array}{c}\% \text { birds whose } \\
\text { requirement } \\
\text { is satisfied }\end{array}$ \\
\hline 7.00 & 0.3847 & 81.1 & 106.3 & $\begin{array}{l}2268 \\
(352)\end{array}$ & 6.3 \\
\hline 7.50 & 0.3794 & 86.9 & 104.2 & $\begin{array}{l}2369 \\
(357)\end{array}$ & 14.9 \\
\hline 8.00 & 0.3758 & 91.8 & 102.7 & $\begin{array}{l}2454 \\
(351)\end{array}$ & 29.2 \\
\hline 8.50 & 0.3738 & 95.4 & 101.5 & $\begin{array}{l}2517 \\
(338)\end{array}$ & 48.0 \\
\hline 8.56 & 0.3736 & 95.7 & 101.4 & $\begin{array}{l}2521 \\
(335)\end{array}$ & 50.0 \\
\hline 9.00 & 0.3732 & 97.7 & 100.8 & $\begin{array}{l}2557 \\
(324)\end{array}$ & 67.0 \\
\hline 9.50 & 0.3737 & 99.0 & 100.4 & $\begin{array}{l}2580 \\
(315)\end{array}$ & 82.4 \\
\hline 10.00 & 0.3750 & 99.6 & 100.1 & $\begin{array}{l}2590 \\
(310)\end{array}$ & 92.4 \\
\hline
\end{tabular}

cannot be easily verified since it has to be applied to each individual. The effect of lysine on abdominal fat content is controversial, as a slight effect has been observed on some but not all genotypes [17]. The latter hypothesis was used in the simulations. It was therefore assumed that dietary lysine exerted a direct effect on weight gain but not on body composition and feed consumption. Further investigations are required to test an iterative process of simulation in which body composition would be dependent on the final weight.

Effects of lysine concentration on gain, final body weight and FCR estimated in those simulations were of the same order of magnitude as observed in recent experiments $[11,17]$, even if the lipid content of gain and the value of the coefficient affected to energy requirement for maintenance could not be determined in most experiments, or were not easy to measure. Results from different simulations seem to confirm that this model is pertinent.

\subsection{Effect of the lipid content of gain}

The correlation coefficient between individual lysine requirements and the lipid contents of gain was always about -0.9 , whatever the simulation. Moreover simulations of Table III and Figure 1 also showed the effect of lipid content on lysine requirement. The hypothesis underlying simulations 4 and 6 was chosen to be in line with the characteristics of a lean and fat line, respectively [15]; our results are very consistent with the 


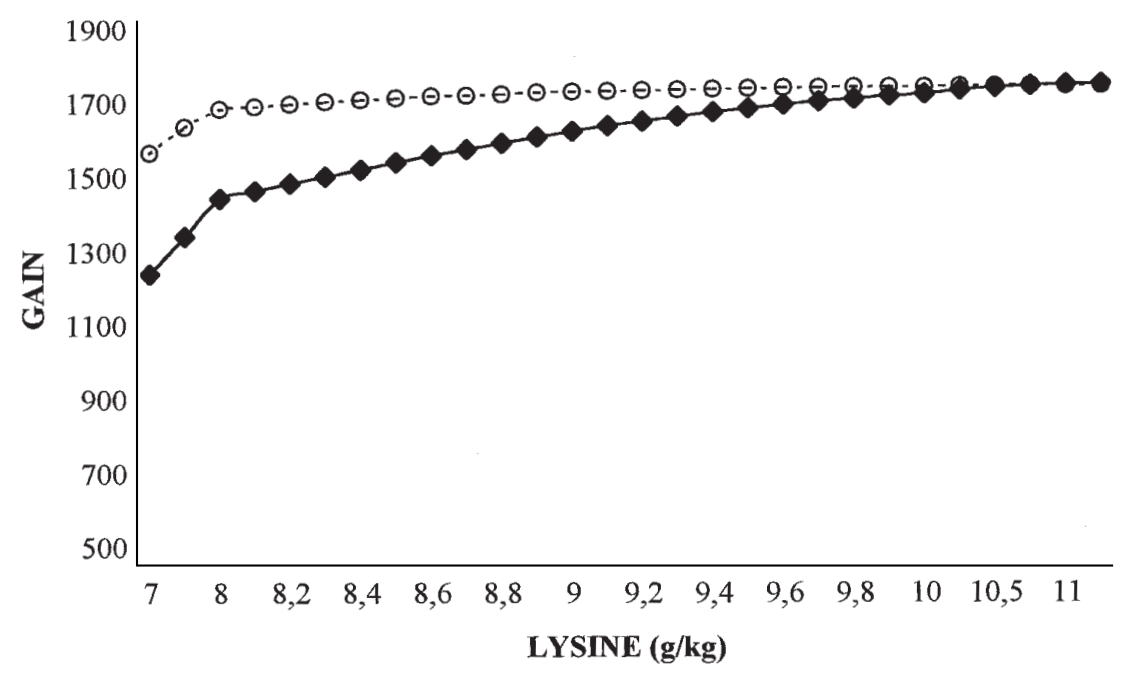

Figure 1. Evolution with dietary Iysine concentration of weight gain between 20 and 40 days of age in a fat $(\bigcirc)$ or lean $(\diamond)$ line.

comparison of such lines [15] which suggests that lipid content has a pronounced influence on lysine requirement within a flock. According to all these results, lean broilers are more sensitive to lysine deficiency and require diets with a higher concentration of this amino acid. Since fatness is a heterogeneous characteristic within commercial flocks, it is likely to be one of the main genetic parameters explaining the curvilinearity of responses of flock performance (gain, live weight and FCR) to variations of dietary lysine concentration. Moreover, heterogeneity of fatness within the flock tends to increase the standard deviation of individual lysine requirement, and, as a consequence, the lysine concentration required to optimise feeding costs. As fatness is highly heritable $[12,16]$, these results show the importance of genetics on nutritional requirements and suggest that selecting broiler chickens for more homogeneous fat content should produce beneficial effects on lysine requirements, flock performance and thus feeding cost.

\subsection{Effect of the factor affecting energy requirement for maintenance}

Genetic differences of energy requirement for maintenance have been mainly observed among lines selected for feed efficiency during growth [18] or at the adult period [8]. As the energy requirement for maintenance cannot be measured routinely, it is not easy to assess the absolute value and the variability of this parameter. Simulations 14 and 17 provided values close to the mean values observed in two experimental lines during the adult period [7]. It is likely that this range of variation could also be reached during the growing period. As shown in Table VI, selection on the basis of this genetic characteristic could provide very beneficial effects on FCR and feeding cost, and should increase lysine requirement.

It is likely that selection for a low FCR, as performed in experimental lines [5, 16, 18], simultaneously leads to reduced fatness and a lower energy requirement for maintenance [18]. Our results suggest that with such 
selection objectives, dietary lysine concentration should be enhanced to allow very lean or efficient birds to exhibit their maximum performance.

\subsection{Effect of lysine concentration on homogeneity of live weight}

As shown in Table VIII, the effect of lysine concentration on live weight was more pronounced when the concentration was below the requirement for both growth and maintenance, which was consistent with equation (9). Above this requirement the effect on mean body weight was lower, but increasing dietary lysine concentration tended to decrease standard deviation of final live weight ( $40 \mathrm{~d}$ of age). This result is in good agreement with what was usually observed in our unpublished nutritional experiments.

\subsection{Economic approach}

Our simulations provide an economic approach of lysine requirement which is based on biological hypotheses instead of empirical observations. With our hypotheses on price it may be concluded that the economic requirement (economic optimum) of different flocks for lysine is always higher than their mean requirements. It is reached on average when the lysine requirement of $65.8 \%$ of individuals is satisfied. If the lysine price increased in comparison with cereal prices, it is likely that the economic optimum for lysine would decrease. From our simulations it can also be concluded that selecting for FCR or leanness should decrease the minimum feeding cost, even if the lysine content of the diet needs to be increased.

It is worth noting that, although lean or efficient genotypes require diets with higher lysine concentrations, they are able to exhibit lower feeding costs per $\mathrm{kg}$ of gain. Similarly, fast growing flocks require diets containing more lysine, but show lower feeding costs.

\subsection{Application to other amino acids}

This model can probably be applied to other amino acids. The first difference would concern the relative values of requirement for maintenance and for growth. For example, as compared to lysine, maintenance requirement is relatively higher than growth requirement for valine and isoleucine, while it is lower for arginine and histidine [4]. As a consequence, responses to different amino acids could be slightly different. Moreover, it should be noted that there is still a large uncertainty about maintenance requirements [4], which requires further investigation [5].

\section{REFERENCES}

[1] Alleman F., Michel J., Chagneau A.M., Leclerca B., Comparative responses of genetically lean and fat broiler chickens to dietary threonine concentration, Brit. Poult. Sci. 40 (1999) 485-490.

[2] Austic R.E., Biochemical description of nutritional effects, in: Fisher C., Boorman K.N (Eds.), Nutrient requirements of poultry and nutritional research, Butterworths, London, 1986, pp. 59-77.

[3] Becker R.A., Chambers J.M., Wilks A.R., The new S language, Wadsworth and Brooks-Cole (Eds.), California, 1988

[4] Boorman K.N., Burgess A.D., Responses to amino acids, in: Fisher C., Boorman K.N (Eds.), Nutrient requirements of poultry and nutritional research, Butterworths, London, 1986, pp. 99-123.

[5] Bordas A., Tixier-Boichard M., Mérat P., Direct and correlated responses to divergent selection for residual food intake in Rhode Island laying hens, Brit. Poult. Sci. 23 (1992) 741-754.

[6] Fisher C., Morris T.R., Jennings R.C., A model for the description and prediction of the response of laying hens to amino acid intake, Brit. Poult. Sci. 14 (1973) 469-484.

[7] Gabarrou J.F., Geraert P.A., François N., Guillaumin S., Picard M., Bordas A., Energy balance of laying hens selected on residual food consumption, Brit. Poult. Sci. 39 (1998) 79-89.

[8] Geraert P.A., Guillaumin S., Bordas A., Mérat P., Evidence of a genetic control of diet induced thermogenesis in poultry, in: Proceedings of the 12th Symposium of energy metabolism of farm animals, EAAP, 58, 1991, pp. 380-383.

[9] Han Y., Baker D.H., Lysine requirement of fast and slow growing broiler chicks, Poult. Sci. 70 (1991) 2108-2114 
[10] Han Y., Baker D.H., Effect of sex, heat stress, body weight and genetic strain on the lysine requirement of broiler chicks, Poult. Sci. 72 (1993) 701-708.

[11] Leclercq B., Specific effects of lysine on broiler production: comparison with threonine and valine, Poult. Sci. 76 (1997) 118-123.

[12] Leclercq B., Genetic selection of meat-type chicken for high or low abdominal fat content, in: Leclercq B., Whitehead C.C. (Eds.), Leanness in domestic birds, Butterworths, London, 1988, pp. 25-40.

[13] Leclercq B., Saadoun A., Selecting broilers for low or high abdominal fat: comparison of energy metabolism of lean and fat lines, Poult. Sci. 61 (1982) 1799-1803

[14] Leclercq B., Cochard T., Chagneau A.M., Hamzaoui S., Larbier M., Comparative utilisation of sulphur-containing amino acids by genetically lean or fat chickens, Brit. Poult. Sci. 34 (1993) 383-391.
[15] Leclercq B., Chagneau A.M., Cochard T., Khoury J., Comparative responses of lean and fat chickens to lysine, arginine and non-essential amino acid supply, Brit. Poult. Sci. 35 (1994) 687-696.

[16] Leenstra F.R., Selection for leanness: results of the Spelderholt experiment, in: Leclercq B., Whitehead C.C. (Eds.), Leanness in domestic birds, Butterworths, London, 1988, pp. 59-69.

[17] Mack S., Bercovici D., DeGroote G., Leclercq B., Lippens M., Pack M., Schutte J.B., VanCauwenberghe S., Ideal amino acid profile and dietary lysine specification for broiler chickens of 20 to 40 days of age, Brit. Poult. Sci. 40 (1999) 257-265.

[18] Pym R.A.E., Nicholls P.J., Thomson E., Choice A., Farrell D.J., Energy and nitrogen metabolism of broilers selected over ten generations for increased growth rate, food consumption and conversion of food to gain, Brit. Poult. Sci. 25 (1984) 529-539. 